\title{
Analysis on the progress of evaporative emission (type IV) standards for light-duty vehicles in China
}

\author{
Chongzhi Zhong*, Taiyu Zhang, and Jiaxing Sun \\ China Automotive Technology and Research Center Co., Ltd
}

Keywords: light-duty vehicles, evaporative emission, emission control, test procedure.

\begin{abstract}
This paper briefly introduces the progress of evaporative emission standards for light-duty vehicles in developed countries such as the United States and Europe, and the test procedures specified in the latest evaporative emission standard were concluded. Moreover, the development of evaporative emission standards for light-duty vehicles in China was comparatively analyzed. The evaporative emission test data from 2004 to 2019 was randomly selected for analysis of the trend of evaporative emission performance of vehicles in China with the use of EPR. Affected by the more stringent China 6 Evaporative Emissions standards issued in 2016, the EPR value of the evaporative emission test conducted according to the China 5 had continuously decreased to $41 \%$ in 2018. Subsequently, the EPR value increased again to a value of $60 \%$ in 2018 and 2019 due to strengthen of the emission limit from $2 \mathrm{~g}$ to $0.7 \mathrm{~g}$ and the raise of deterioration factor. Finally, based on the world's latest evaporative emission standards, the development trend of evaporative emission standards for light-duty vehicles in China is forecasted. The application of canister bench aging test, BETP, running loss emission test, and a test cycle with Chinese characteristics may be more conducive to control the light-duty vehicle emissions. Compared with the LEV 3, the evaporative emission limit of $0.7 \mathrm{~g} / \mathrm{test}$ specified in China 6 is still relatively larger. In addition, strengthen the control of durability test and in-use emission performance test would makes the $\mathrm{HC}$ emission less during the actual operation of the vehicle.
\end{abstract}

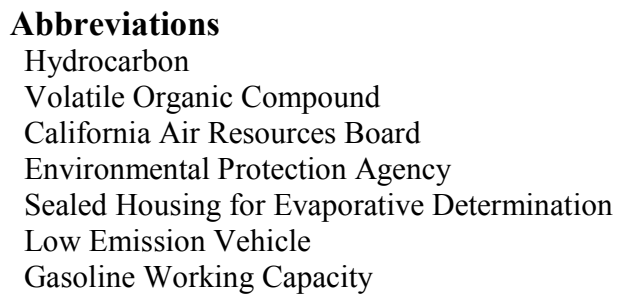

* Corresponding author: zhongchongzhi@catarc.ac.cn 


\author{
Bleed Emission Test Procedure \\ European Economic Commission \\ European Economic Community \\ European Union \\ New Europe Driving Cycle \\ World Light Vehicle Test Cycle \\ Emission Performance Ratio
}

\section{Introduction}

A report from the Ministry of Ecology and Environment of the People's Republic of China showed that the automobile hydrocarbon (HC) emission in China was 3.267 million tons in $2018^{[1]}$, and $\mathrm{HC}$ is one of the main pollutants emitted by light vehicles. Fuel combustion is a well-known direct source of carbonyls emissions to the atmosphere ${ }^{[2]}$. The main component of evaporative emissions is $\mathrm{HC}$, accounting for about $20 \%$ of total $\mathrm{HC}$ emissions from vehicles ${ }^{[3]}$.In China, a vehicle could produce $8.2 \mathrm{~kg}$ of evaporative volatile organic compounds (VOCs) each year, which is researched by the Manufacturers of Emission Controls

Association $(\mathrm{MECA})^{[4]}$. In addition, Yamada et al. ${ }^{[5]}$ estimated that a gasoline vehicle may produce approximately $443 \mathrm{~g}$ evaporative emissions each year, and gasoline evaporative evaporation from vehicles was the sixth-highest source of VOCs in Japan ${ }^{[6]}$. Martini et al. ${ }^{[7]}$ estimated that a small-sized vehicle could produce approximately $1000 \mathrm{~g} /$ year evaporative emissions in two Italian provinces. Liu et al. ${ }^{[8]}$ and Man et al. ${ }^{[9]}$ estimated the evaporative emissions under different test procedures, including diurnal test, hot soak test, refueling test, and permeation test, and found that evaporative emissions are increasingly crucial to total VOCs emissions in China. The reduction of $\mathrm{HC}$ emission has always been one of the focuses of pollution control. China has been learning from the European emission standards since the China 1 to formulate the evaporative emission standards. The evaporative emission limits of China 5 standards implemented in 2018 was the same as the limits in the China 1 standards implemented in $2000^{[10]}$. The evaporative emission limit of $0.7 \mathrm{~g} /$ test in the latest China 6 evaporative emission standard was tightened by $65 \%$ compared with the China 5 evaporative emission standard. In addition, the China 6 evaporative emission standard also learned from the US emission standards, and the refueling emission test was added in. With the further strengthened emission standards, the strict extent of the China 6 evaporative emission limit has exceeded that of Europe, and it is closer to the US emission standard which is regarded as the most stringent emissions standards in the world.

The progress of evaporative emission standards for light-duty vehicle in China was analyzed, and the development process and latest test procedure of European and American evaporative emission standards were briefly summarized in this paper. A reference for the formulation of more stringent evaporative emission standards in the future can be provided through the statistical analysis of evaporative emission test data from 2014 to 2019 .

\section{Progress of evaporative emission control standard in foreign countries}

\subsection{Progress of evaporative emission control in America}

\subsubsection{Progress of evaporative emission standard in America}


The automobile emission standards in the United States are promulgated by the California Air Resources Board (CARB) and the Environmental Protection Agency (EPA) respectively. In general, the CARB emission standards were implemented 1 or 2 years earlier than the EPA emission standards.

In the early 1970s, the United States first implemented evaporative emission standards to limit fuel vapor emissions. Hot soak, diurnal, and running loss emissions tests were included in the first evaporative emission standards with the use of the "canister capture method". Subsequently, the test method was changed from "canister capture method" to Sealed Housing for Evaporative Determination (SHED) method for 1978 model year vehicles. The "Enhanced Evaporative" emissions standards were promulgated in 1990 by CARB and 1993 by EPA. A hot soak + 2-day diurnal test, a high temperature hot soak + 3day diurnal test, and a running loss test were included in the "Enhanced Evaporative" emissions standards. The emission standards were further strengthened in 1999 with that the CARB formally passed LEV (low emission vehicle) 2 and the EPA passed "transition" Tier 2 standards. The LEV 2 standard is stricter than the Tier 2 standard in hot soak $+2 / 3-$ dirurnal test procedures ${ }^{[11]}$. To further control the vehicle emission, the CARB began to implement LEV 3 in 2013 and the EPA began to implement Tier 3 in 2017 respectively. In terms of hot soak and diurnal emission limits, LEV 3 is $40 \%$ stricter than LEV 2, and Tier 3 is also $40 \%$ stricter than Tier 2 .

\subsubsection{The latest evaporative emission standards in America}

The main test procedures and emission limits of LEV 3 and Tier 3 are the same, but the temperature specified in LEV 3 is higher than Tier 3 for hot soak and diurnal tests. The temperature of hot soak test is $40.5^{\circ} \mathrm{C}$ specified in LEV 3 and $35^{\circ} \mathrm{C}$ specified in Tier 3 . The temperature cycle range is $18.3-40.6^{\circ} \mathrm{C}$ specified in LEV 3 and $22.2-35.6^{\circ} \mathrm{C}$ specified in Tier 3. There are two main test procedures including a hot soak +2 -diurnal and a running loss + high temperature hot soak +3 -day diurnal test. In additional, bleed emission test procedure (BETP) was also ruled to measure the amount of $\mathrm{HC}$ bleed emission from the purge port of the canister after the fuel tank and canister system had been cycled between $65^{\circ} \mathrm{F}$ and $105^{\circ} \mathrm{F}$ according to the 2-day diurnal test. In BETP, the canister system shall be stabilized to a 4000-mile test condition using no less than $10 \mathrm{GWC}$ cycles or driving the vehicle for 4000 miles. For the emission limit, the test result must meet one of the following two situations: hot soak + diurnal emission value shall not exceed $0.35 \mathrm{~g} /$ test and the value of fuel evaporation emission is $0 \mathrm{~g}$, or hot soak + diurnal emission value does not exceed $0.3 \mathrm{~g} /$ test and the test result of BETP does not exceed $0.02 \mathrm{~g} /$ test. In addition, the running loss emission result shall not be greater than $0.03 \mathrm{~g} / \mathrm{km}$. In terms of test procedures, there are more test procedures including running loss test and BETP in LEV/Tier 3 compared with China 6 . In terms of the strict extent of the emission limit, the Tier/LEV 3 with the emission limit value of $0.3 / 0.35 \mathrm{~g} /$ test is also more stringent than China 6 with the emission limit value of $0.7 \mathrm{~g} / \mathrm{test}$.

\subsection{Progress of evaporative emission control in Europe}

\subsubsection{Progress of evaporative emission standard in Europe}

In European, the vehicle emissions are controlled by the European Economic Commission (ECE) emission standards and the European Economic Community (EEC) which is the predecessor of later the European Union (EU). Europe initially issued ECE-15 in 1970 to 
control the emission of pollutants from automobiles. In 199, the ECE revised the R83-00 regulations to form the Euro 1 emission standards, which came into effect in $1992^{[12]}$. In the subsequent process, the evaporative emission standards system had been improved constantly. At present, the latest evaporative emission standard is Euro $6 \mathrm{D}$ emission standard.

The emission standards of China 1 and 2 are equivalent to the emission standards of Euro 1 and Euro 2. The evaporative emissions test procedures in Euro 1 and Euro 2 mainly included 1 hour diurnal emission test and 1 hour hot soak test. In the emission test, the sum of the experiment result of diurnal emission test and hot soak test cannot exceed the limit of $2 \mathrm{~g} /$ test. Since Euro 3, the evaporative emission test procedures changed significantly. The evaporative emission test procedures of Euro 3, Euro 4 and Euro 5 mainly included 24h diurnal emission test and $1 \mathrm{~h}$ hot soak emission test. And the emission limit was still $2 \mathrm{~g}$. In 2014, Euro 6 emission standards began to be implemented in Europe. For the diurnal emission test procedures, the test cycle in Euro $6 \mathrm{a}$ and Euro $6 \mathrm{~b}$ was still $24 \mathrm{~h}$, and the specific experimental conditions were the same as Euro 5. However in Euro 6c and Euro 6d, the test cycle was changed to $48 \mathrm{~h}^{[13]}$. From Euro 1 to Euro 6, the NEDC test cycle was used in the vehicle preconditioning drive. As of the latest Euro $6 \mathrm{D}$ emission standards, the NEDC test cycle is no longer used and it is changed to the WLTC test cycle.

\subsubsection{The latest evaporative emission standards in Europe}

In the latest Euro $6 \mathrm{D}$ evaporative emission standards, the test procedures are classified according to whether the vehicle is equipped with a sealed fuel tank system. In addition to the hot soak and 2-day diurnal test procedures, the measurement of depression puff loss overflow which is also called BETP shall be performed on the vehicles equipped with sealed fuel system after the tank relief valve was opened, and the test result shall be $0 \mathrm{~g}$. In addition to the main test procedure for vehicle evaporative emissions, a bench aging test for canister and a 20 -week permeability factor(PF) determination test for fuel tank system were also added. The canister bench aging test included the vibration test, the temperature cycling test, the 300 cycles GWC test, and at least 5 cycles BWC test. Through above tests, the $\mathrm{HC}$ adsorption capacity of the canister will be somewhat reduced. The difference value of the $\mathrm{HC}$ emission of the fuel tank after 3-week and 20-week fuel immersion according to the 1-day diurnal test shall be measured to determine the value of PF which is used to calculate the final test results. In addition, the manufacturer may choose to use the assigned value of $\mathrm{PF}$ factor $\mathrm{APF}=0.12 \mathrm{~g}$ instead of performing the complete measurement procedure mentioned above if the multilayer tanks or metal tanks was equipped on the vehicles. The Final result of the evaporative emission test specified in Euro 6D was the sum of hot soak test result, the 1st-day diurnal test result, the 2nd-day diurnal test result, and 2 times PF. The pretreatment processes of the canister and fuel tank are equivalent to tightening the emission limit, but the emission limit is still $2 \mathrm{~g}$ which is still looser than that of China 6 . Compared with the evaporative emission test procedures in the United States, there are still no standards about refueling emissions and running loss specified in Euro6.

\section{Analysis on the progress of evaporative emission standards for light-duty vehicles in China}

\subsection{Analysis on the evaporative emission standards from China 1 to China 6}

As early as 1993, the use of the collection method to measure the evaporative emission was specified in GB / T14763-1993. Subsequently, evaporative emission standard specified in 
Euro 1 was adopted equivalently in China 1 and $\mathrm{HC}$ emission can be tested by using the SHED or collection method ${ }^{[14]}$. The test procedure mainly included hot soak emission test, diurnal emission test and vehicle precondition drive test on the chassis dynamometer. For bi-fuel vehicles, their evaporative emissions are measured when only fuel is used. The China 2 standard stipulated that the SHED method shall be used for the evaporative emission test, and the collection method was no longer used. The flow charts of evaporative emission test procedures from China 1 to China 6 are showed in Figure 1.

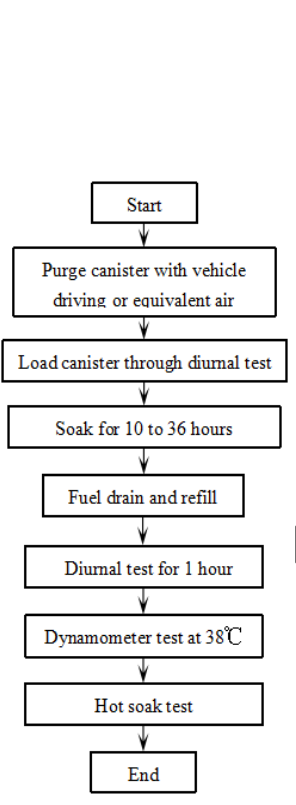

(a) China $1 / 2$

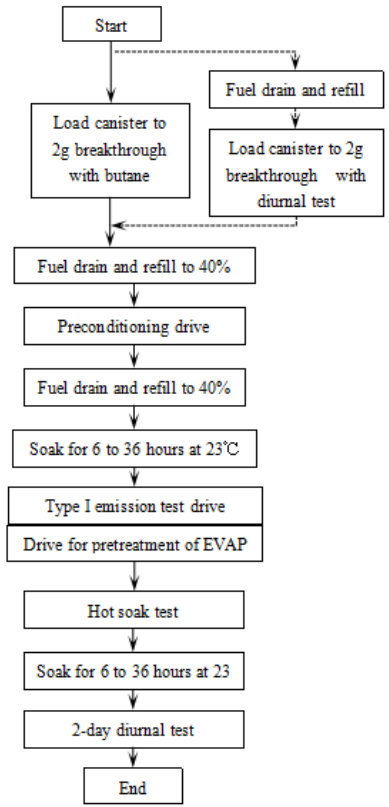

(b) China $3 / 4 / 5$

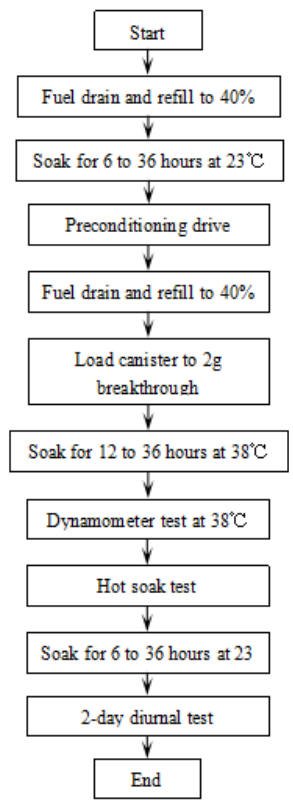

(c) China 6 without NIRCO

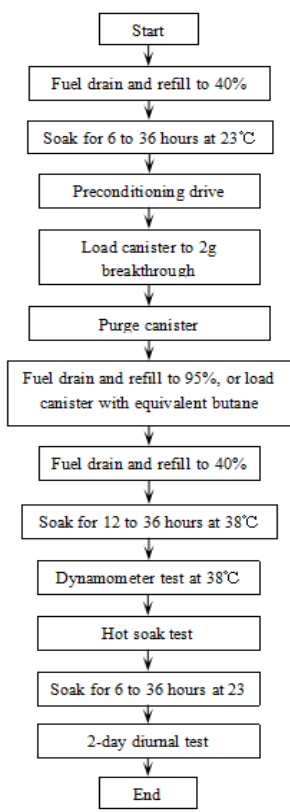

(d) China 6 with NIRCO

Fig. 1. Evaporative emission test procedures from China 1 to China 6.

The evaporative emission test procedures of China 1 and China 2 are the same. The evaporative emission test procedures of China 3, China 4 and China 5 are the same, and there were only slightly changes on the duration for the soak of the vehicle in China 5 . In terms of test procedure, large changes had been made in China 6 compared with China 5 . From the analysis on the progress of evaporative emission standards for light-duty vehicles in China, China 1 and China 2 can be regarded as a stage, country 3 to country 5 can be regarded as a stage, and country 6 is a stage. The evaporative emission test conditions from China 1 to China 6 are summarized in Table 1.

Table 1. Test conditions from China 1 to China 6.

\begin{tabular}{cccc}
\hline Emission standard & China 1/2 & China 3/4/5 & China 6 \\
\hline $\begin{array}{c}\text { Duration(day) } \\
\text { Test Procedure for }\end{array}$ & 2 & 4 & 5 \\
NIRCO & $/$ & $/$ & new \\
$\begin{array}{c}\text { Pretreatment for } \\
\text { canister }\end{array}$ & $\begin{array}{c}\text { Vehicle driving, air } \\
\text { purge, diurnal test }\end{array}$ & $\begin{array}{c}\text { Butane/gasoline } \\
\text { loading to 2g } \\
\text { breakthrough, vehicle } \\
\text { driving }\end{array}$ & $\begin{array}{c}\text { Butane loading to 2g } \\
\text { breakthrough, vehicle } \\
\text { driving }\end{array}$ \\
Test Cycle & NEDC & NEDC & WLTC \\
\hline
\end{tabular}




\begin{tabular}{|c|c|c|c|}
\hline $\begin{array}{l}\text { Temperature for hot } \\
\text { soak test }\left({ }^{\circ} \mathrm{C}\right)\end{array}$ & $23-31{ }^{\circ} \mathrm{C}$ & $23-31{ }^{\circ} \mathrm{C}$ & $38 \pm 2^{\circ} \mathrm{C}$ \\
\hline $\begin{array}{l}\text { Temperature for } \\
\text { diurnal test }\left({ }^{\circ} \mathrm{C}\right)\end{array}$ & $\begin{array}{l}\text { Fuel tank heating, } \\
\text { linear temperature } \\
\text { increase within } 16- \\
30^{\circ} \mathrm{C}\end{array}$ & $\begin{array}{l}\text { SHED, temperature } \\
\text { cycle within } 20-35^{\circ} \mathrm{C}\end{array}$ & $\begin{array}{l}\text { SHED, temperature } \\
\text { cycle within } 20-35^{\circ} \mathrm{C}\end{array}$ \\
\hline $\begin{array}{l}\text { Duration for diurnal } \\
\text { test(hour) }\end{array}$ & 1 & 24 & 48 \\
\hline $\begin{array}{l}\text { Deterioration factor } \\
(\mathrm{g} / \mathrm{test})\end{array}$ & / & I & 0.06 \\
\hline $\begin{array}{l}\text { Calcuation of test } \\
\text { result }\end{array}$ & $\begin{array}{l}\text { Hot soak }+ \text { diurnal } \\
\text { emission test result }\end{array}$ & $\begin{array}{l}\text { Hot soak }+ \text { diurnal } \\
\text { emission test result }\end{array}$ & $\begin{array}{l}\text { Hot soak }+\operatorname{Max}(1 \text { st- } \\
\text { day, 2nd-day diurnal) } \\
\text { emission test result }\end{array}$ \\
\hline Emission limit(g/test) & 2 & 2 & $0 / 7$ \\
\hline
\end{tabular}

\subsubsection{Comparative analysis of test cycle}

The test cycle adopted by China 1 to China 5 is the NEDC, as shown in Figure 2(a), which is mainly composed of an urban test cycle and an extra-urban test cycle. While the test cycle used by China 6 is the WLTC as shown in Figure 2(b), and the test cycle is divided into four parts: low phase, medium phase, high phase and extra high phase. It can be found from the velocity-time curve in figure 2 that the speed distribution of NEDC, which is basically composed of uniform velocity, uniform acceleration, and uniform deceleration, is relatively regular and the vehicle is in a stable operating condition. Throughout the WLTC cycle, the speed is constantly changing without fixed pattern, and it is closer to the actual vehicle driving road condition.

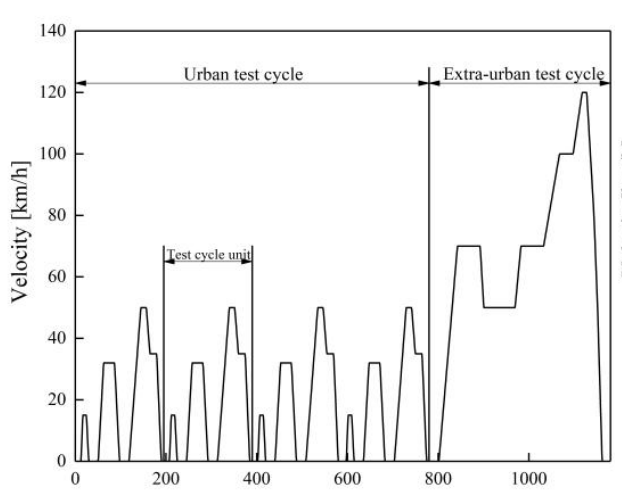

(a) NEDC

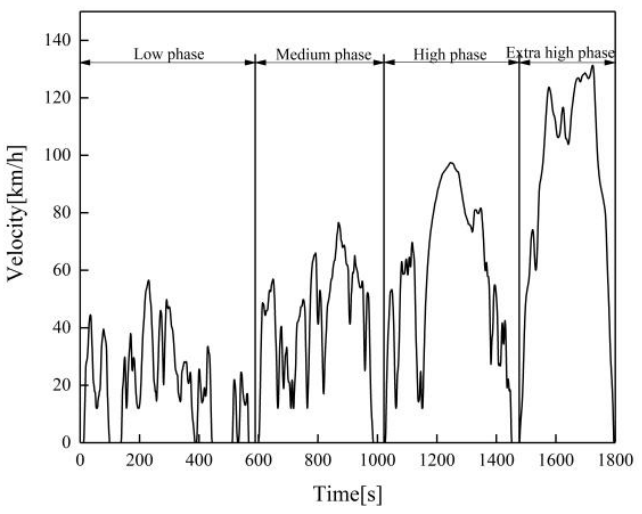

(b) WLTC

Fig. 2. Velocity profile of NEDC and WLTC.

The test conditions of NEDC and WLTC is compared in Table 2. With the combination of the data shown in Table 2, it can be seen that WLTC has a higher maximum speed, higher average speed, higher maximum acceleration, and lower proportion of idling condition compared with NEDC test cycle.

Table 2. Comparison of NEDC and WLTC.

\begin{tabular}{ccc}
\hline Test cycle & NEDC & WLTC \\
\hline Composition & $\begin{array}{c}\text { An urban test cycle and } \\
\text { an extra-urban test cycle }\end{array}$ & $\begin{array}{c}\text { A low phase, a medium phase, a } \\
\text { high phase, and an extra high }\end{array}$ \\
\hline
\end{tabular}




\begin{tabular}{ccc}
\hline & & phase \\
Duration $(\mathrm{s})$ & 1180 & 1800 \\
Mileage $(\mathrm{km})$ & 11.04 & 23.27 \\
Velocity range $(\mathrm{km} / \mathrm{h})$ & $0-120$ & $0-131.3$ \\
Average velocity $(\mathrm{km} / \mathrm{h})$ & 33.68 & 46.54 \\
Max acceleration/ deceleration & $+1.04 /-1.39$ & $+1.67 /-1.50$ \\
$\left(\mathrm{~m} \cdot \mathrm{s}^{-2}\right)$ & 24.8 & 13.2 \\
\hline Idling proportion $(\%)$ & &
\end{tabular}

\subsubsection{Comparative analysis of pretreatment for canister}

In the test procedures of China 1 and China 2, the way to run the vehicle at $60 \mathrm{~km} / \mathrm{h}$ or equivalent air volume is used to purge the canister, and the canister is loaded with gasoline through twice diurnal emission tests without the requirement of $2 \mathrm{~g}$ breakthrough. In the test procedures from China 3 to China 5, the canister shall be loaded to $2 \mathrm{~g}$ breakthrough with butane or gasoline through reheating the fuel tank, and the canister shall be purged through the running of the vehicle before the hot soak and diurnal emission test. Compared with China 5, the method of loading canister with gasoline was eliminated in China 6.

\subsubsection{Comparative analysis of hot soak test process}

From China 1 to China 5, the temperature of hot soak test shall be controlled within the range of $23-31^{\circ} \mathrm{C}$, while the temperature of the hot soak test was increased to $38 \pm 2^{\circ} \mathrm{C}$ in China 6. Yue et al. found that the $\mathrm{HC}$ emissions can be increased with the increasing of the temperature during the hot soak test ${ }^{[15]}$. On the basis of that there is no change on the emission limits, raising the temperature of the hot soak test is equivalent to tightening the emission control.

\subsubsection{Comparative analysis of diurnal emission test process}

With the continuous upgrading of emission standards, the temperature cycle of diurnal emissions test is also closer to the actual situation. In China 1 and China 2, the diurnal emission test was performed with the method of heating the fuel tank, and the fuel tank with the initial temperature of $16{ }^{\circ} \mathrm{C}$ was heated according to the mathematical formula $\mathrm{T}=$ $\mathrm{T}_{0}+0.2333 \mathrm{t}$ in an hour. From China 3 to China 5, the duration of diurnal emission test was lengthened to one day, and the temperature cycle was changed as shown in Figure 3, which is closer to the actual day and night temperature change in the actual situation. In China 6, the duration of diurnal emission test was extended from one day to two days, and the temperature cycle of the second day is the same as the first day. The larger value of the first-day and the second-day diurnal test result shall be taken as the final diurnal emission test result. 


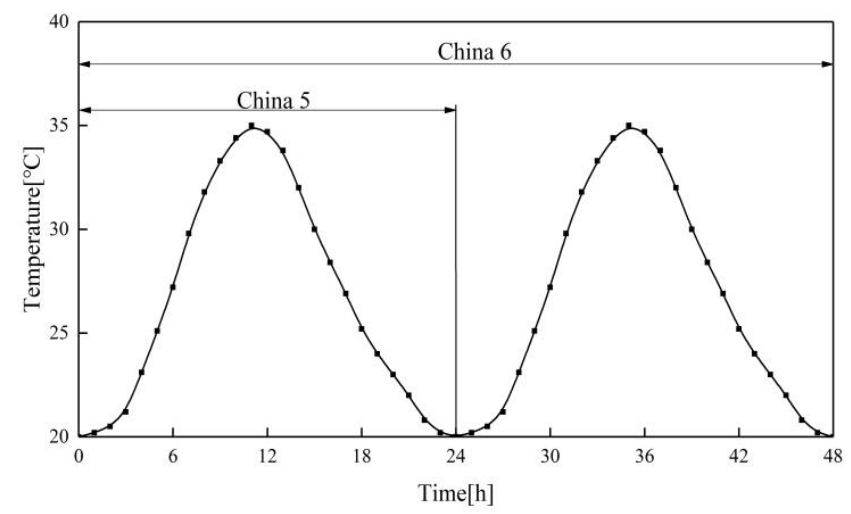

Fig. 3. Temperature cycle of diurnal emission test.

\subsubsection{Comparative analysis of emission limits}

From China 1 to China 5, the emission limit was $2 \mathrm{~g} /$ test, while the emission limit was tightened to $0.7 \mathrm{~g} /$ test in China 6 . In China 6 , it was the first time that the deterioration factor with the value of $0.06 \mathrm{~g} /$ test was adopted, and the sum of the experiment result and deterioration factor shall be less than the emission limit specified in China 6. In lieu of assigned deterioration factor with the value of $0.06 \mathrm{~g} / \mathrm{test}$, the value of deterioration factor can be obtained through durability test with the method of the linear regression.

\subsection{Analysis on the performance of the vehicle evaporative emissions in recent years}

In 2001, the Ministry of Environmental Protection officially promulgated China 1 and China 2 to control the light-duty vehicle emissions, which were required to be implemented in 2001 and 2004 respectively. The China 3 and China 4 for light-duty vehicle emission control were promulgated in 2005 and implemented in 2007; The China 5 for light-duty vehicle emission control were promulgated in 2013 and implemented in 2018; In 2016, China 6 for light-duty vehicle emission control were promulgated and required to be implemented in 2020. Before the official promulgation of the emission standards, the Ministry of Environmental Protection will generally send a draft to enterprises for comments one year in advance. In order to analyze the performance of vehicle evaporative emissions in recent years, the vehicle evaporative emission test data which meets the emission limits from 2004 to 2019 are selected. The test data of 20 vehicles were selected randomly for each year. Besides, the data of 40 vehicles including 20 vehicles for China 5 and 20 vehicles for China 6 were selected in 2018. The selected vehicles were manufactured by different manufacturers, covering private enterprises, state-owned enterprises, foreign enterprises, and joint venture enterprise. The test data from 2004 to 2019 is shown in Figure 4. 


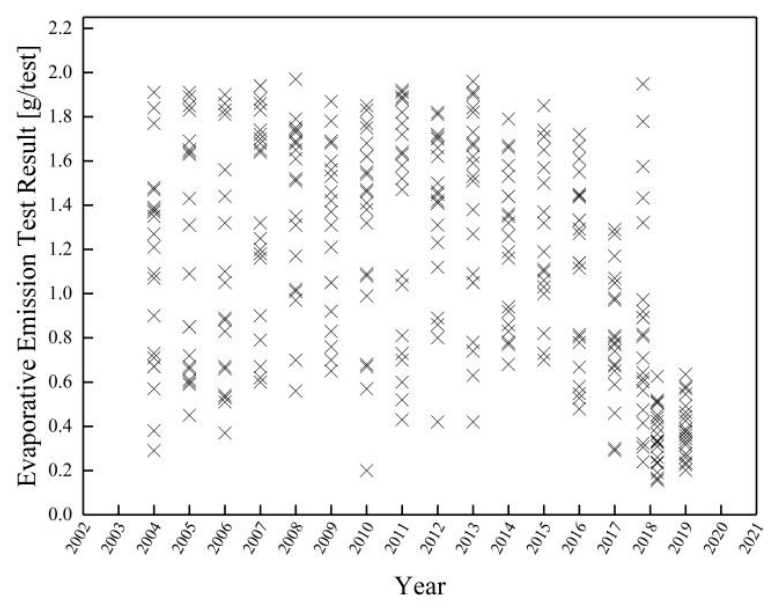

Fig. 4. Evaporative emission test data from 2004 to 2019.

The evaporative emission test results for vehicles tested in 2004-2018 covered data from China 3, China 4, and China 5, and the test results for vehicles tested in 2018-2019 covered data from China 6. Since the deterioration factor was adopted in China 6, the emission test data showed in Figure 4 are the sum of the test results and the deterioration factor. Due to the different evaporative emission limits of corresponding evaporative emission standards, it is helpful to compare the evaporative emission performance of vehicles in different years on the same test basis with the use of Emissions performance ratio or EPR where EPR $=($ hot soak + diurnal test result + deterioration factor $)$ divided by the limit of corresponding emission standards [3]. This approach is reasonable since the evaporative emission control technology on most vehicles within an emission standard varies only slightly. The average EPR over time from 2004 to 2019 was showed in Figure 5.

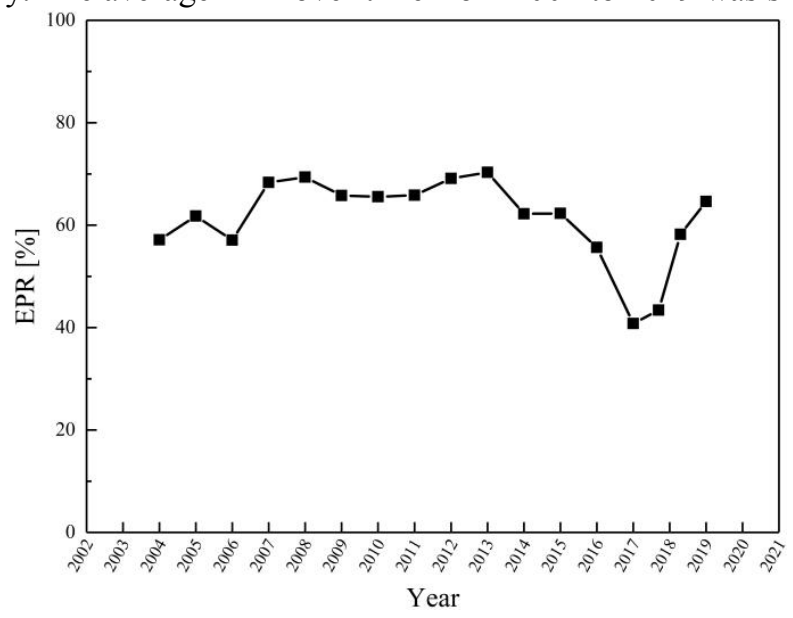

Fig. 5. The average EPR over time from 2004 to 2019.

It can be seen from Figure 5 that the EPR value keeps fluctuating within the range of $57-70 \%$ in 2004-2015 with the same evaporative emission test procedure specified in China 3, China 4, and China 5. Affected by the more stringent evaporative emissions standards of China 6 issued in 2016, the EPR value of the evaporative emission test conducted according to the China 5 test procedures in 2016-2018 has continuously decreased to $41 \%$. Due to the strengthen of the emission limit from $2 \mathrm{~g}$ to $0.7 \mathrm{~g}$ and the added deterioration 
factor in China 6, the EPR value raised again to a value of $60 \%$ in 2018 and 2019. In summary, the vehicle's evaporative emission control technology was optimized according to the changes in the evaporative emission test procedures and limit specified in different standards, and the EPR value of the vehicle fluctuated within the range of 50-70\%.

\section{Conclusions}

(1) In terms of the canister bench aging test procedures, vibration test, the temperature cycling test, GWC test, and the BWC test specified in the latest Euro 6 D standard can effectively evaluate the durability characteristics of canister, which is conducive to increase the focus on enhancing the durability of carbon canisters and reduce the possibility of the increase of $\mathrm{HC}$ emissions due to the long-term use of the canister.

(2) At current, the LEV 3 is the most strict evaporative emission standard with the emission limits dropped as low as $0.3 \mathrm{~g} /$ test. Compared with the LEV 3 , the evaporative emission limit of $0.7 \mathrm{~g} /$ test specified in China 6 is still relatively loose.

(3) The $\mathrm{HC}$ emission during BETP after the tank relief valve was opened shall be $0 \mathrm{~g}$, which was specified in Euro 6 D. The HC emission limit during BETP under the condition of diurnal emission test was also specified in LEV 3/Tier 3. No emission limit for BETP has been put forward in China.

(4) The running loss emission test was adopted as early as in LEV/Tier 2, which is helpful to control the $\mathrm{HC}$ emissions of the vehicle when driven on road. But the standard about running loss emission test is still in a blank stage in China.

(5) At present, durability and in-use emission performance test for evaporative emission of China 6 are not mandatory, which makes the $\mathrm{HC}$ emission control of the long-term used vehicle inadequate.

(6) In view of the test cycle conditions, the WLTC used in China 6 was compiled by the Economic Commission for Europe, and it is still different from the actual driving conditions. China has a large land area and complicated terrain. Therefore, a test cycle with Chinese characteristics is more conducive to control the light-duty vehicle emissions.

(7) When a vehicle manufacturer conducts research and development work under different evaporative emission standards, the EPR value can be controlled between 50 to $70 \%$ to optimize the vehicle's evaporative emission control technology.

On behalf of all the authors, the corresponding author states that there is no conflict of interest.

\section{References}

1. Ministry of Ecology and Environment of the People's Republic of China: China Mobile Source Environmental Management Annual Report for 2019. Ministry of Ecology and Environment of the People's Republic of China Web. http://www.mee.gov.cn/hjzl/sthjzk/ydyhjgl/201909/P020190905586230826402.pdf. Accessed 4 September 2019

2. McLaren, R., Singleton, DL., Lai, JK., Khouw, B., Singer, E., Wu, Z.: Analysis of motor vehicle sources and their contribution to ambient hydrocarbon distributions at urban sites in Toronto during the southern Ontario oxidants study. Atmos Environ. 30, 2219-2232 (1966).

3. Meng, H.: Evaporative emission control for gasoline car. J. Quality and Standardization, 317(09), 64-66 (2018)

4. M.E.C.A.: Reducing evaporative emissions-the largest source of VOC emissions leading to haze, PM2.5 and ozone formation in China's major cities: a macro and 
micro analysis with information on international experience and related implications for China. Manufacturers of Emission Controls Association, Arlington, VA

5. Yamada, H., Inomata, S., Tanimoto, H.: Evaporative emissions in three-day diurnal breathing loss tests on passenger cars for the Japanese market. Atmos. Environ. 107, 166-173 (2015)

6. Yamada, H.: Contribution of evaporative emissions from gasoline vehicles toward total VOC emissions in Japan. Sci. Total Environ. 449, 143-149 (2013).

7. Martini, G., Paffumi, E., Gennaro, M.D., Mellios, G.: European type-approval test procedure for evaporative emissions from passenger cars against real world mobility data from two Italian provinces. Sci. Total Environ. 487, 506-520 (2014).

8. H. Liu, H. Man, M. Tschantz, Y. Wu, K. He, J. Hao: VOC from vehicular evaporation emissions: status and control strategy, Environ. Sci. Technol. 49(24), 14424-14431 (2015)

9. H. Man, H. Liu, Q. Xiao, Fan Deng, Q. Yu, K. Wang, Z. Yang, Y. Wu, K. He, J. Hao, How ethanol and gasoline formula changes evaporative emissions of the vehicles, Appl. Energy 222(15), 584-594 (2018)

10. Zhu, R. , Hu, J. , Bao, X. , He, L. , Lai, Y. , \& Zu, L.: Investigation of tailpipe and evaporative emissions from china iv and tier 2 passenger vehicles with different gasolines. Transportation Research Part D Transport \& Environment. 50, 305-315 (2017)

11. Passavant, G.: Summary and analysis of 2000-2015 model year iuvp evaporative and refuling emission data. SAE Technical Paper. 2017-01-5008 (2017).

12. Wang, x., Tian, D., Wang, J.: Analysis of similarities and differences of the evaporative emission standards in Europe and America. Beijing Automotive Engineering. 05, 4-6+10 (2013)

13. Trent, J.W.: Analysis on vehicle emission standard and key emission parameters measurement. Dissertation, Qingdao University of Technology (2016)

14. Cheng, Y., Fu, T., Li Y., Gao, J., Fang, M.: Status quo and analysis of evaporative emission from domestic light-duty gasoline vehicle. Automotive Engineering. 03, 8-12 (2002)

15. Campbell, S.L., Gear, C.W.: Characteristics of evaporative emissions from light-duty vehicle and effects of ambient temperature on evaporative emissions of light-duty vehicles. Research of environmental sciences. 33(1), 73-81 (2020) 